\title{
PENGARUH PARTISIPASI DALAM PENYUSUNAN ANGGARAN \\ TERHADAP KINERJA MANAJERIAL DENGAN MOTIVASI, PELIMPAHAN WEWENANG DAN PENGETAHUAN MANAJEMEN BIAYA SEBAGAI MODERATING ( Studi Pada Satuan Kerja Perangkat Daerah (SKPD) Se-Provinsi Riau)
}

\author{
Suwarno $^{1}$, Kamaliah $^{2}$, dan Zulbahridar ${ }^{2}$ \\ ${ }^{1}$ Program Studi Magister Akuntansi Pasca Sarjana Universitas Riau, Pekanbaru \\ ${ }^{2}$ Fakultas Ekonomi Universitas Riau, Pekanbaru \\ Email : suwarnos2unri@gmail.com
}

\begin{abstract}
Abstrak: Penelitian ini bertujuan menguji pengaruh partisipasi anggaran terhadap kinerja manajerial pada SKPD se-Provinsi Riau dengan motivasi, pelimpahan wewenang dan pengetahuan manajemen biaya sebagai variabel moderating. Populasi dalam penelitian ini adalah 38 SKPD se-Provinsi Riau dengan responden sebanyak 304 orang. Pengumpulan data sampel mengambil sebanyak 152 responden dengan cara membagikan kuesioner. Jenis data yang digunakan adalah data primer dengan metode pengumpulan data menggunakan kuesioner. Penelitian ini bertujuan mengetahui pengaruh partisipasi penyusunan anggaran terhadap kinerja manajerial SKPD se-Provinsi Riau dengan motivasi, pelimpahan wewenang dan pengetahuan manajemen biaya sebagai variabel moderating. Metode analisis data yang digunakan dalam penelitian ini adalah regresi berganda. Hasil penelitian ini menunjukkan bahwa partisipasi penyusunan anggaran berpengaruh terhadap kinerja manajerial dengan signifikansi o,o01. Pengetahuan manajemen biaya dapat memoderasi pengaruh partisipasi penyusunan anggaran terhadap kinerja manajerial dengan signifikansi o,o35. Motivasi dan pelimpahan wewenang tidak memoderasi pengaruh partisipasi anggaran terhadap kinerja manajerial karena masing-masing mempunyai signifikansi 0,743 dan 0,106 Hasil koefisien determinasi sebesar 0.772. Angka ini menjelaskan bahwa 77,2\% kinerja manajerial dipengaruhi partisipasi anggaran, motivasi dan pengetahuan manajemen biaya, sedangkan sisanya $22,8 \%$ kinerja manajerial dijelaskan oleh variabel lainnya, seperti pelimpahan wewenang dan lain-lain.

Kata Kunci : Partisipasi Penyusunan Anggaran, Motivasi, Pelimpahan Wewenang, Pengetahuan Manajemen Biaya, dan Kinerja Manajerial.
\end{abstract}

\section{PENDAHULUAN}

Kinerja manajerial merupakan faktor yang mendukung keefektifan organisasi. Mahoney et.al dalam Puspaningsih (2002) melihat kinerja manajer berdasar pada kemampuan manajer dalam melaksanakan tugas manajerialnya. Kinerja (performance) merupakan gambaran mengenai tingkat capaian pelaksanaan suatu kegiatan/program/kebijakan dalam mewujudkan sasaran, tujuan, visi dan misi organisasi yang tertuang dalam strategic planning suatu organisasi (Mahsun, 2006). Kinerja manajerial merupakan suatu proses pelaksanaan fungsi-fungsi manajemen, dimana terdapat interaksi antara 
bawahan dengan atasan yang berkaitan dengan usahan dan kegiatan untuk merencanakan, mengarahkan dan mengendalikan prestasi kerja karyawan.

Partisipasi anggaran membutuhkan keterlibatan tidak hanya manajer tingkat atas, tetapi juga manajer tingkat bawah dalam proses penyusunan anggaran. Penelitian mengenai partisipasi anggaran dalam sektor publik terutama kaitannya dengan kinerja manajerial penting untuk dilakukan karena perilaku penganggaran (budgetary behaviour) dalam sektor publik terutama pemerintah berbeda dengan perilaku penganggaran dalam perusahaanperusahaan yang berorientasi laba (profit oriented) Haryanto dkk, (2007). Partisipasi dalam penyusunan anggaran merupakan pendekatan manajerial yang umumnya dinilai dapat meningkatkan kinerja manajerial (Sinambela, 2003).

Penelitian dilakukan oleh Govindarajan (1986), Browwnell dan Mclnnes (1986), Indriantoro (1993) dalam Supomo (1998) menemukan adanya pengaruh positif partisipasi dalam proses penyusunan anggaran yang merupakan pendekatan manajerial terhadap perilaku dan kinerja manajerial. Penelitian lain menyatakan bahwa hubungan antara partisipasi penyusunan anggaran dengan kinerja manajerial dipengaruhi oleh Motivasi (Brownell dan Mclnnes, 1986; Mia, 1988), dan sikap terhadap pekerjaan dan perusahaan ( Millani, 1975; Mia, 1988).

Motivasi atau dorongan adalah suatu pendorong yang dapat mendorong manusia untuk melakukan sesuatu tindakan dorongan (tenaga) atau suatu pendorong tersebut merupakan gerak hati (jiwa) maupun jasmani untuk bertindak atau berbuat atau sesuatu yang melatar belakangi manusia berbuat sesuatu untuk mencapai keinginannya atau tujuannya (Mohyi 1996).

Pelimpahan wewenang dan desentralisasi merupakan salah satu dasar yang harus ada dalam organisasi. Pelimpahan wewenang adalah pemberian wewenang oleh manajer yang lebih tinggi kepada manajer yang lebih rendah untuk melaksanakan suatu pekerjaan dengan otorisasi secara eksplisit dari manajer pemberi wewenang pada waktu wewenang tersebut dilaksanakan (Mulyadi dan setyawan, 2000). Hal ini didukung dengan penelitiannya Gul dkk (1995), bahwa partisipasi anggaran terhadap kinerja akan berpengaruh positif dalam organisasi yang pelimpahan wewenangnya bersifat desentralisasi. Sedangkan Riyanto (1996) menemukan sebaliknya, yaitu desentralisasi tidak berpengaruh positif terhadap kinerja manajerial.

Pengetahuan manajemen biaya menjadi variabel moderasi dalam menguji pengaruh partisipasi anggaran terhadap kinerja manajerial karena kemampuannya untuk menjadi pedoman dalam menyusun anggaran untuk meningkatkan pengendalian terhadap biaya agar memperbaiki kinerja manajerial sehingga dapat memperkuat pengaruh dari variabel independen (partisipasi anggaran) terhadap variabel dependen (kinerja manajerial).

Menurut Agbejuledan Saarikoski (2006), pengetahuan manajemen biaya berpengaruh positif antara partisipasi anggaran terhadap kinerja manajerial. Sedangkan Shields dan Young (1994) tentang pengetahuan manajemen biaya tidak berpengaruh positif antara partisipasi anggaran terhadap kinerja manajerial. Pada prinsipnya penyusunan anggaran yang dilaksanakan oleh 
pemerintah daerah berpedoman pada Peraturan Menteri Dalam Negeri No.13 Tahun 2006, di mana dalam penyusunan rencana keuangan tahunan dilakukan secara terintegrasi untuk seluruh jenis belanja guna melaksanakan kegiatan pemerintahan yang didasarkan pada prinsip pencapaian efisiensi alokasi dana.

\section{TINJAUAN PUSTAKA DAN PENGEMBANGAN HIPOTESIS}

\section{Konsep Motivasi Kerja Teori Harapan (Expectancy Theory)}

Menurut Vroom (1964) Ketiga teori motivasi yang paling banyak memberikan kontribusinya terhadap falsafah manajemen kinerja adalah yang berkenaan tujuan (goals),dorongan (Reinforcement) dan harapan ( Expectancy). Teori harapan sebagaimana yang dikembangkan oleh Vroom (1964) dalam Surya Dharma (2005) menyatakan bahwa agar dapat meningkatkan motivasi untuk menunjukkan kinerja tinggi, karyawan harus: 1)Merasa mampu mengubah perilaku mereka. 2)Merasa yakin bahwa perubahan perilaku mereka dapat menghasilkan imbalan. 3)Memberikan nilai imbalan yang memadai sehingga membawa perubahan perilaku. Sedangkan Wibowo( 2007) menjelaskan kinerja ditentukan oleh tujuan yang hendak dicapai dan untuk melakukannya diperlukan adanya motif.

\section{Teori Penetapan Tujuan ( Goal-Setting)}

Menurut Wibowo ( 2007) Tujuan adalah sebagai apa diharapkan untuk dicapai oleh suatu organisasi, fungsi, departemen, dan individu dalan suatu periode waktu tertentu. Arti pentingnya menetapkan tujuan adalah sebagai proses manajemen yang memastikan bahwa setiap pekerja individual tahu peran apa yang harus mereka lakukan dan hasil apa yang mereka capai untuk memaksimumkan kontribusinya pada keseluruan bisnis. Locke (1998) mengemukakan bahwa maksud-maksud untuk bekerja ke arah suatu tujuan merupakan sumber utama dari motivasi kerja. Cascio (1987) dalam Sekaran (1992) menyatakan bahwa pengarahan tingkah laku terhadap suatu tujuan manjadi dasar goal setting. Secara umum pengertian goal setting itu adalah penetapan sasaran atau target yang akan dicapai tenaga kerja.

\section{Partisipasi Anggaran}

Partisipasi Anggaran adalah proses dimana bawahan atau pelaksana anggaran diberikan kesempatan untuk terlibat dalam proses penyusunan anggaran dan mempunyai pengaruh pada proses penyusunan anggaran. Kesempatan yang diberikan diyakini meningkatkan pengendalian dan rasa keterlibatan dikalangan bawahan/pelaksana anggaran (Chong, 2002). Pengertian partisipasi dalam proses penyusunan anggaran lebih rinci dijelaskan oleh French et al, (1966) sebagai suatu proses kerjasama dalam pembuatan keputusan yang melibatkan dua kelompok atau lebih yang berpengaruh pada pembuatan keputusan di masa yang akan datang. Dari penjelasan diatas, dapat disimpulkan bahwa partisipasi dalam penyusunan anggaran merupakan tingkat keterlibatan bawahan dan atasan dalam penyusunan anggaran.

\section{Partisipasi Penyusunan Anggaran}


Partisipasi adalah keterlibatan individu yang bersifat mental dan emosional dalam situasi kelompok bagi pencapaian tujuan bersama dan berbagi tanggungjawab bersama. Partisipasi yang diberikan oleh individu bukan hanya aktivitas fisik tetapi juga sisi psikologis, yaitu seberapa besar pengaruh yang dianggap memiliki seseorang dalam pengambilan keputusan Wiryono dan Raharjo (2007). Partisipasi dalam proses penganggaran merupakan pendekatan yang efektif untuk meningkatkan motivasi manajer. Dengan tingkat partisipasi yang tinggi cenderung mendorong manajer untuk lebih aktif didalam memahami anggaran (Antony dan Govindarajan, 1995), dan manajer akan memiliki pemahaman yang baik dalam menghadapi kesulitan pada saat pelaksanaan anggaran.

\section{Partisipasi Anggaran dan Kinerja Manajerial.}

Partisipasi anggaran merupakan suatu proses yang melibatkan individuindividu secara langsung di dalamnya dan mempunyai pengaruh terhadap penyusunan tujuan anggaran yang prestasinya akan dinilai dan kemungkinan akan dihargai atas dasar pencapaian tujuan anggaran mereka (Brownell, 1982). Kinerja manajerial yang dimaksud dalam penelitian ini yakni kinerja kepala dinas, kepala bidang, kepala bagian, kepala seksi, dan kepala sub bidang, kepala sub bagian, kepala sub seksi. Dalam kegiatan manajerial yang mencakup perencanaan, pelaksanaan, penatausahaan, laporan, pertanggungjawaban, pembinaan dan pengawasan. Variabel kinerja manajerial diukur dengan menggunakan instrumen self rating yang dikembangkan oleh Mahoney (1963) dalam Alfar (2006), di mana setiap responden diminta untuk mengukur kinerja sendiri ke dalam delapan dimensi, yaitu perencanaan, investigasi, pengkoordinasian, evaluasi, pengawasan, pemilihan staf, negosiasi, dan perwakilan, serta satu dimensi pengukuran kinerja seorang kepala dinas, kepala bagian dan kepala bidang secara keseluruhan. Terdapat tiga macam ukuran yang dapat digunakan untuk mengukur kinerja secara kuantitatif yaitu : 1) Ukuran kriteria tunggal (Single criterium). 2) Ukuran kriteria beragam (Multiple criterium). 3) Ukuran kriteria gabungan (Composite criterium).

\section{Kelemahan Partisipasi dalam Proses Penyusunan Anggaran}

Siegel dan Marconi (1989) menyatakan bahwa partisipasi memungkinkan terjadinya perilaku disfungsional, misalnya menciptakan slack atau senjangan anggaran, dimana para manajer tingkat bawah tidak akan memberikan seluruh informasi yang mereka miliki pada saat penyusunan anggaran. Permasalahan lain dalam partisipasi adalah terjadinya pseudoparticipation (Hansen dan Mowen, 1997), suatu perusahaan menyatakan menggunakan partisipasi dalam penyusunan anggaran padahal sebenarnya tidak dilakukan.

\section{Anggaran, Penganggaran, Fungsi dan Manfaat Anggaran}

Mardiasmo (2002) mengemukakan anggaran merupakan pernyataan mengenai estimasi kinerja yang hendak dicapai selama periode tertentu yang dinyatakan dalam ukuran finansial. Anggaran adalah rencana tertulis mengenai kegiatan suatu organisasi yang dinyatakan secara kuantitatif dan umumnya dalam satuan uang jangka waktu tertentu (Nafarin, 2000). 
Sedangkan Munandar, (1986) memberikan difinisi tentang anggaran yaitu suatu rencana yang dinyatakan dalam unit (kesatuan) moneter dan berlaku untuk jangka waktu (periode) tertentu yang akan datang. Mardiasmo (2002) menjelaskan anggaran publik berisi rencana kegiatan yang direpresentasikan dalam bentuk rencana perolehan pendapatan dan belanja dalam satuan moneter. Menurut Wiryono dan Raharjono (2007) Proses penyusunan anggaran diawali dengan pembuatan atau penentukan pedoman anggaran.

\section{Motivasi}

Motivasi merupakan keadaan dalam pribadi seseorang yang mendorong keinginan individu untuk melakukan kegiatan tertentu guna mencapai suatu tujuan. Motivasi yang ada pada saat diri seseorang akan mewujudkan suatu perilaku yang diarahkan pada tujuan mencapai sasaran kepuasan. Gitosudarsono dan Sudita(1997) dalam Marani dan Supomo (2003) mengatakan bahwa proses timbulnya motivasi seseorang merupakan gabungan dari konsep kebutuhan, dorongan,tujuan dan imbalan, sedangkan Mitchell (1982) menjelaskan motivasi merupakan derajat sampai sejauhmana individu ingin dan berusaha dalam mengerjakan suatu pekerjaan dengan baik dan upaya yang tinggi kearah tujuan organisasi akan dikondisikan oleh upaya untuk memenuhi kebutuhan individual. Penyusunan anggaran dimaksudkan bukan hanya untuk menyajikan informasi mengenai rencana keuangan yang berisi tentang biaya-biaya dan pendapatan pusat-pusat pertanggungjawaban suatu organisasi bisnis, tetapi juga merupakan suatu alat untuk pengendalian, koordinasi, komunikasi, evaluasi kerja dan motivasi (Kenis, 1979).

\section{Pelimpahan Wewenang}

Pelimpahan wewenang adalah pemberian wewenang oleh manajer yang lebih tinggi kepada manajer yang lebih rendah untuk melaksanakan suatu pekerjaan dengan otorisasi secara eksplisit dari manajer pemberi wewenang pada waktu wewenang tersebut dilaksanakan (Mulyadi dan setyawan, 2000). Pelimpahan wewenang dan desentralisasi merupakan salah satu dasar yang harus ada dalam organisasi. Pelimpahan wewenang merupakan masalah yang harus diperhatikan oleh para manajer apabila membuat struktur organisasi.

\section{Pengetahuan Manajemen Biaya}

Manajemen biaya merupakan bentuk akuntansi manajemen yang memungkinkan sebuah bisnis untuk memprediksi pengeluaran yang akan datang untuk membantu mengurangi kemungkinan akan melebihi anggaran yang telah ditetapkan perusahaan. Tujuan dari manajemen biaya adalah menyediakan informasi untuk membantu manajemen dalam menggunakan sumber-sumber dengan cara yang paling menguntungkan. Manajemen biaya bermanfaat bagi manajemen dalam membantu perencanaan dan pengendalian yaitu digunakan untuk mengumpulkan dan melacak kinerja keuangan dan operasional mengenai aktivitas perusahaan dan peyediaan umpan balik antara hasil sesungguhnya dengan yang direncanakan (Supriyono, 1999). Manajemen biaya juga bermanfaat untuk digunakan sebagai alat pengambil keputusan agar perusahaan dapat bertahan hidup dan mencapai tujuan. 


\section{Telaah Hasil Penelitian Sebelumnya}

Brownell ( 1982b) melakukan studi lapangan terhadap 48 manajer pusat biaya level menengah yang bekerja pada perusahaan-perusahaan manufaktur skala besar di San Fransisco. Penelitian yang menggunakan instrumen Milani (1975) untuk mengukur partisipasi dalam penyusunan anggaran dan instrumen Mahoney dkk, (1975) untuk mengukur kinerja manajerial tersebut, menemukan hubungan positif dan signifikan antara partisipasi dengan kinerja manajerial. Indriantoro (1993) Penelitian ini menunjukkan bahwa partisipasi penyusunan anggaran dengan kinerja manajerial mempunyai hubungan yang positif dan signifikan. Sementara hasil penelitian Milani (1975); Brownel dan Hirst (1986) dan Riyanto (1999), dan Poerwati (2001) menunjukkan bahwa terdapat hubungan yang tidak signifikan diantara keduanya. Sterdy (1960); Bryan dan locke (1967) dan Supomo (1998) menemukan hubungan yang negatif antara partisipatif dengan kinerja manajerial. Keterkaitan antara partisipasi penyusunan anggaran dengan motivasi telah banyak dilakukan oleh penelitian-penelitian terdahulu, dan hasilnya dapat disimpulkan adalah adanya hubungan yang positif ( Kenis, 1979; Merchant, 1981; serta Brownell dan Mclnnes, 1986). Hasil dari penelitian mereka dapat digeneralisasi, namun harus berhati-hati dalam menggeneralisasikannya karena faktor budaya (French dkk, 1996) dan sifat-sifat kepribadian (personality) ( brownell, 1981) juga mempengaruhi interaksi antara partisipasi dengan motivasi. Mia (1998), hasil penelitiannya menunjukkan bahwa motivasi mempuyai pengaruh positif terhadap kinerja manajerial. Sedangkan Riyadi (1988), hasil penelitiannya menunjukkan bahwa motivasi tidak mempenpunyai pengaruh positif terhadap kinerja manajerial. Gul et al (1995) menemukan bahwa pelimpahan wewenang yang bersifat sentralisasi akan berpengaruh positif terhadap kinerja manajerial. Sedangkan Riyanto (1996) menemukan sebaliknya, yaitu desentralisasi tidak berpengaruh positif terhadap kinerja manajerial.

\section{Kerangka Pemikiran}

\section{Pengaruh Partisipasi Dalam Penyusunan Anggaran Terhadap Kinerja Manajerial}

Partisipasi merupakan suatu konsep dimana bawahan ikut terlibat dalam pengambilan keputusan sampai tingkat tertentu bersama atasannya. Partisipasi mendorong manajer untuk mengidentifikasi tujuan, menerimanya dengan suatu komitmen dan bekerja agar dapat mencapainya dan akhirnya meningkatkan kinerja manajer (Chong and Chong, 2002). Partisipasi dalam penyusunan anggaran merupakan hal yang signifikan untuk dipertimbangkan sebagai faktor yang berpengaruh terhadap keefektifan suatu organisasi (Indriantoro, 1995).

\section{Pengaruh Motivasi Terhadap Hubungan Antara Partispasi Dalam Penyusunan Anggaran Dengan Kinerja Manajerial}

Pengaruh motivasi terhadap hubungan antara partisipasi dalam penyusunan anggaran dengan kinerja manajereial, setiap perusahaan atau organisasi pemerintah bukan saja mengharapkan bawahannya yang mampu, 
cakap dan trampil, tetapi yang terpenting mau bekerja giat dan berkeinginan untuk mencapai hasil kerja yang optimal. Motivasi sangat penting karena dengan motivasi diharapkan setiap individu mau bekerja keras dan antusias untuk mencapai produktivitas kerja yang tinggi. Sebagaimana dikatakan oleh Mohyi ( 1996).

\section{Pengaruh Pelimpahan Wewenang Terhadap Hubungan Antara Partispasi Dalam Penyusunan Anggaran Dengan Kinerja Manajerial}

Pelimpahan wewenang merupakan suatu pemberian yang menjadi hak atas tugas dan tanggung jawab untuk melakukan sesuatu atau memerintah orang lain untuk melakukan sesuatu. Sebagaimana dikatakan (Mulyadi dan setyawan, 2000) dalam Marani dan Supomo (2003) pelimpahan wewenang adalah pemberian wewenang oleh manajer yang lebih tinggi kepada manajer yang lebih rendah untuk melaksanakan suatu pekerjaan dengan otorisasi secara eksplisit dari manajer pemberi wewenang pada waktu wewenang tersebut dilaksanakan. Merchant (1981) menemukan bahwa desain sistem anggaran akan efektif dalam organisasi yang terdesentralisasi. Berbeda dengan Gul et al. (1995) menemukan bahwa pelimpahan wewenang berpengaruh positif terhadap kinerja manajerial.

Pengaruh Pengetahuan Manajemen Biaya Terhadap Hubungan Antara Partispasi Dalam Penyusunan Anggaran Dengan Kinerja Manajerial

Pengetahuan manajemen biaya dapat memainkan peran penting dalam menentukan kemanjuran partisipasi anggaran. Tingkat pengetahuan manajemen biaya partisipan bisa mempengeruhi keputusan terkait anggaran, dan secara konsekuen kinerja. Partisipasi dengan pengetahuan manajemen biaya yang rendah bisa menjadi detrimental karena individu dengan tingkat pengetahuan manajemen biaya yang rendah dapat mengurangi kualitas dari keputusan anggaran dan kinerja secara keseluruhan (Scully et al., 1995). Kinerja manajerial merupakan hasil dari proses aktivitas manajerial yang efektif mulai dari proses perencanaan, pelaksanaan, penatausahaan, laporan pertanggungjawaban, pembinaan, dan pengawasan. Mahoney dkk, (1993) kinerja manajerial adalah kinerja para individu anggota organisasi dalam kegiatan-kegiatan manajerial seperti; perencanaan, investigasi, koordinasi, pengaturan staf, negosiasi dan representasi.

\section{Hipotesis Penelitian}

H1 : Partisipasi berpengaruh dalam penyusunan anggaran terhadap kinerja manajerial.

H2 : Motivasi berpengaruh terhadap hubungan antara partisipasi dalam penyusunan anggaran dengan kinerja manajerial.

H3 : Pelimpahan wewenang berpengaruh terhadap hubungan antara partisipasi dalam penyusunan anggaran dengan kinerja manajerial.

H4 : Pengetahuan manajemen biaya berpengaruh terhadap hubungan antara partisipasi dalam penyusunan anggaran dengan kinerja manajerial. 


\section{METODOLOGI}

\section{Disain Penelitian, Jenis, dan Metode Pengumpulan Data}

Rancangan penelitian yang akan digunakan untuk menganalisis penelitian ini adalah tipe penelitian penjelasan (explanatory / confirmatory research). Kuesioner yang dikirimkan disertai dengan surat permohonan serta penjelasan tentang tujuan penelitian yang dilakukan. Petunjuk pengisian kuisioner dibuat sederhana dan sejelas mungkin untuk memudahkan pengisian jawaban sesungguhnya dengan lengkap. Penyebaran kuesioner dilakukan dengan cara langsung diantarkan ke SKPD se-Provinsi Riau tempat yang diteliti.

\section{Populasi, Sampel dan Pengambilan Sampel}

Populasi adalah wilayah generalisasi yang terdiri atas obyek/subyek yang mempunyai kualitas dan karakteristik tertentu yang ditetapkan oleh peneliti untuk dipelajari dan kemudian ditarik kesimpulannya (Sugiyono, 2006). Populasi dalam penelitian ini adalah para pengguna anggaran yaitu Kepala Dinas atau Instansi dan Kepala Bidang pada SKPD se-Provinsi Riau yang berjumlah 304 Responden. Teknik pemilihan dan penentuan sampel dalam penelitian ini adalah rata-rata atau tiap instansi SKPD Provinsi Riau diambil jumlah sampel yang sama. Berdasarkan tabel di atas responden yang berjumlah 304 dari 38 instansi yang berada dalam lingkungan SKPD Provinsi Riau.

\section{Variabel Penelitian dan Definisi Operasional Variabel}

Dalam penelitian ini, variabel dependen (Y) yang digunakan adalah kinerja manajerial sedangkan variabel independennya terdiri dari partisipasi penyusunan anggaran (X1), motivasi kerja (X2), dan pelimpahan wewenang (X3) serta pengetahuan manajemen biaya $\left(\mathrm{X}_{4}\right)$.

Kinerja manajerial diukur dengan menggunakan enam item pernyataan yang menggambarkan tingkat kinerja manajerial dalam perencanaan, pengorganisasian, evaluasi, pengawasan, pemilihan staf (staffing). Partisipasi penyusunan anggaran diukur dengan menggunakan enam item pernyataan yang menggambarkan keikutsertaan dalam penyusunan anggaran, permintaan tentang anggaran kepimpinan, revisi anggaran, pembuatan rencana dalam anggaran akhir ( final), kontribusi terhadap anggaran, pendapat atau usulan pada saat anggaran (RKA) sedang disusun. Motivasi diukur dengan menggunakan dua puluh satu item pernyataan yang menggambarkan tingkat persepsi responden terhadap bagaimana keinginan pribadi apabila mengerjakan sesuatu dengan sangat baik, bentuk imbalan dan kesempatan setelah mengerjakan sesuatu dengan sangat lebih baik, dan tujuan pribadi bekerja keras dalam pekerjaan. Pelimpahan wewenang diukur dengan menggunakan enam item pernyataan yang menggambarkan pengangkatan dan pemindahan hubungan kerja pegawai dari pimpinan/kepala dinas atau instansi, pengalokasiaan anggaran, spesifikasi pelaksanaan tugas, pedoman kerja, keputusan operasional, dan cara pembuatan keputusan para pimpinan. Responden diminta menjawab tentang pengetahuan dan kemampuan mereka akan manajemen biaya dengan memilih di antara tujuh skala jawaban. 


\section{Analisis Regresi}

Pengujian hipotesis dilakukan dengan menggunakan model analisis regresi berganda bertujuan untuk memprediksi berapa besar kekuatan pengaruh variabel independen terhadap variabel dependen. Persamaan regresinya adalah :

$\mathrm{Y}=\beta_{\mathrm{o}}+\beta_{1} \mathrm{X}_{1}+\beta_{2} \mathrm{X}_{2}+\beta_{3} \mathrm{X}_{3}+\beta_{4} \mathrm{X}_{4}+\beta_{5} \mathrm{X}_{1} \mathrm{X}_{2}+\beta_{6} \mathrm{X}_{1} \mathrm{X}_{3}+\beta_{7} \mathrm{X}_{1} \mathrm{X}_{4}$

Dimana;

$\mathrm{Y} \quad=$ kinerja manajerial

Bo $\quad=$ intersep

$\beta 1, \beta 2, \ldots . ., \beta 7=$ koefisien regresi

$\mathrm{X} 1=$ partisipasi dalam penyusunan anggaran

$\mathrm{X} 2=$ motivasi dalam penyusunan anggaran

$\mathrm{X}_{3}=$ pelimpahan wewenang dalam penyusunan anggaran

$\mathrm{X}_{4} \quad=$ pengetahuan manajemen biaya

$\mathrm{X} 1 \mathrm{X} 2=$ interaksi antar partisipasi dan motivasi dalam penyusunan anggaran

$\mathrm{X}_{1} \mathrm{X}_{3}=$ interaksi antar partisipasi dan pelimpahan wewenang dalam penyusunan anggaran

$\mathrm{X}_{\mathrm{X}} 4 \quad=$ interaksi antar partisipasi dan pengetahuan manajemen biaya dalam penyusunan anggaran

\section{HASIL PENELITIAN DAN PEMBAHASAN Analisa Deskriptif}

Dari survey yang telah dilakukan selama pertengahan bulan Juni sampai Juli 2013 diperoleh sejumlah 152 responden. Dari sebanyak 152 kuisioner yang disebar tersebut, ternyata ada sebanyak 17 kuisioner yang tidak kembali atau datanya tidak lengkap dalam pengisian. Sehingga kuisioner yang kembali dan lengkap datanya sebanyak 135 kuisioner.

\section{Validitas dan Reliabilitas Kuisioner}

Ketepatan pengujian suatu hipotesa tentang hubungan variabel penelitian sangat tergantung pada kualitas data yang dipakai dalam pengujian. Maka dalam penelitian ini dilakukan uji validitas dan reliabilitas untuk mengetahui apakah data yang dipakai untuk menguji hipotesa adalah data yang reliabel atau tidak dan dapat menggambarkan secara tepat konsep yang diukur atau tidak. Berdasarkan perhitungan yang dilakukan, diperoleh nilai $\mathrm{r}$ Alpha $=0,8235$, dimana angka ini lebih besar dari nilai $r$ kritik Product Moment $=0,12183$, sehingga dapat dikatakan item-item pertanyaan yang disusun dalam kuisioner ini sudah reliabel.

\section{Normalitas}


Pada pengujian normalitas bertujuan untuk mengetahui bahwa dalam model regresi, variabel yang diukur yaitu variabel terikat dan variabel bebas keduanya mempunyai distribusi normal atau tidak. Hasil plot normal, tampak pada gambar di bawah ini;

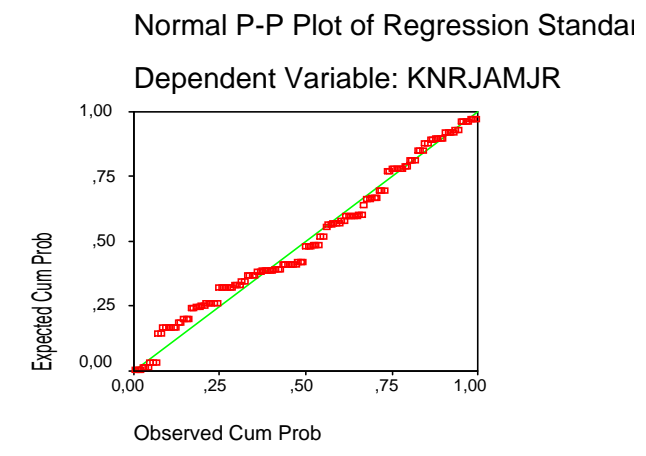

Dari hasil olahan SPSS yang ditunjukkan oleh gambar diatas dapat dikatakan bahwa grafik tersebut terlihat titik-titik menyebar di sekitar garis diagonal, serta penyebarannya mengikuti arah garis diagonal atau mendekati garis lurus. Jadi grafik ini menunjukkan bahwa model regresi pada penelitian ini layak dipakai karena memenuhi asumsi normalitas. Dalam penelitian ini untuk menilai partisipasi anggaran digunakan 6 pertanyaan. Total skor jawaban responden diperoleh sebesar 2501 dengan nilai minimal sebesar 1920, nilai maksimal sebesar 3360, dan rata-rata skor sebesar 5,21 dan Kriteria posisi sebesar 74,43\%. Kriteria 74,43\% termasuk di posisi 69\% - 83\% (sangat baik).

\section{Asumsi Klasik}

Untuk melihat apakah ada tidaknya heteroskedastisitas pada suatu model persamaan regresi adalah dengan mengeplot antara nilai Y prediksi (sumbu Y) dengan residualnya ( sumbu X). Jika terjadi pola tertentu maka dapat dikatakan terjadi heteroskedastisitas dan sebaliknya. Adapun hasil plotnya adalah sebagai berikut:

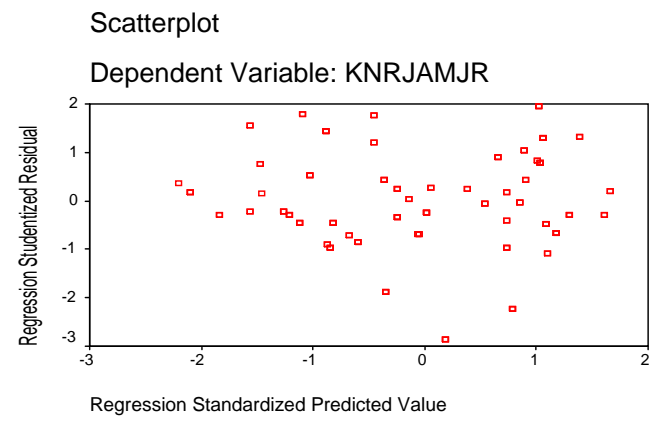

Pada gambar diatas dapat dikatakan tidak terjadi pola tertentu sehingga dapat disimpulkan tidak terjadi heteroskedastisitas, dengan kata lain model tersebut dikatakan model persamaan yang homoskedastisitas.

\section{Analisis Regresi Berganda}

Pada model persamaan regresi berganda ini akan diuji apakah variabel Motivasi, Pelimpahan Wewenang dan Pengetahuan Manajemen Biaya adalah 
sebagai variabel moderating dari variabel Partisipasi terhadap Kinerja Manajerial. Model lengkapnya sebagai berikut:

$\mathrm{Y}=\beta_{0}+\beta_{1} \mathrm{X}_{1}+\beta_{2} \mathrm{X}_{2}+\beta_{3} \mathrm{X}_{3}+\beta_{4} \mathrm{X}_{4}+\beta_{5} \mathrm{X}_{1} \mathrm{X}_{2}+\beta_{6} \mathrm{X}_{1} \mathrm{X}_{3}+\beta_{7} \mathrm{X}_{1} \mathrm{X}_{4}$

Dari hasil output SPSS diatas, maka persamaan regresi bergandanya secara lengkap adalah sebagai berikut:

$\mathrm{Y}=-5,355+2,244 \mathrm{X} 1+0,001372 \mathrm{X} 2+0,636 \mathrm{X}_{3}+0,657 \mathrm{X}_{4}+$ $\mathrm{0}, 04435 \mathrm{X}_{1} \mathrm{X} 2-0,170 \mathrm{X}_{1} \mathrm{X}_{3}+0,178 \mathrm{X} 1 \mathrm{X}_{4}$.

Untuk mengetahui fit atau tidaknya persamaan regresi berganda yang telah terbentuk, maka diperlukan uji F. Sesuai dengan hasil perhitungan Uji F yang dilakukan dengan bantuan program SPSS diperoleh nilai $\mathrm{F}$ hitung sebesar 62,972 yang berarti lebih besar daripada nilai $\mathrm{F}$ tabel yaitu 2,08. Dengan demikian Ho ditolak dan H1 diterima, artinya variabel bebas (Partisipasi, Motivasi, Pelimpahan Wewenang, Pengetahuan Manajemen Biaya dan interaksi) memiliki pengaruh yang signifikan secara bersama terhadap variabel $\mathrm{KM}$ (Kinerja Manajerial) dinas SKPD Provinsi Riau.

Prosentase pengaruh variabel bebas (Partisipasi, Motivasi dan Pengetahuan Manajemen Biaya) terhadap variabel terikat (Kinerja Manajerial) yang ditunjukkan oleh koefisien determinasi simultan, (Rsquared) adalah sebesar 77,2\%. Sedangkan sisanya sebesar 22,8\% dipengaruhi oleh variabel-variabel lain, selain variabel Partisipasi, Motivasi dan Pengetahuan Manajemen Biaya. Dengan kata lain kontribusi variabel Partisipasi, Motivasi dan Pengetahuan Manajemen Biaya terhadap tingkat perubahahan Kinerja Manajerial adalah sebesar 77,2\%. Sedangkan kontribusi dari variabellain di luar adalah sebesar 22,8\%. Berdasarkan nilai Kd $\left(\mathrm{R}^{2}\right)$ yang sebesar 77,2\% maka berarti Partisipasi, Motivasi dan Pengetahuan Manajemen Biaya secara simultan maupun parsial, sangatberpengaruh terhadap Kinerja Manajerial dalam penyusunan anggaran pada SKPD Provinsi Riau. Dengan demikian dari hasil uji good nes of fit model yang dipakai mengetahui fit tidaknya model tersebut mempunyai kesimpulan fit diantara variable bebas yang ada sebesar 0,878 .

\section{Pengujian Hipotesis dan Pembahasannya}

Partisipasi dalam penyusunan anggaran berpengaruh terhadap Kinerja Manajerial SKPD. Hasil pengolahan data diketahui bahwa nilai thitung $=3,487>$ ttabel $=1,960$, yang artinya menolak Ho. Hal ini menunjukkan bahwa Partisipasi karyawan (bawahan) berpengaruh cukup signifikan dan pengaruhnya bersifat positif terhadap kinerja manajerial, artinya semakin tinggi tingkat partisipasi karyawan (bawahan) dalam proses penyusunan anggaran, maka akan meningkatkan Kinerja Manajerial (atasan) di dinas SKPD Provinsi Riau dan sebaliknya.

Motivasi berpengaruh terhadap hubungan antara Partisipasi dalam penyusunan anggaran dengan Kinerja Manajerial SKPD. Hasil pengolahan data diketahui nilai thitung $=0,326<\mathrm{t}$-tabel $=1,960$, yang artinya menerima Ho. Ini berarti bahwa Motivasi tidak memoderasi hubungan antara Partisipasi dengan Kinerja Manajerial. Tapi Motivasi berpengaruh langsung terhadap Kinerja Manajerial. Hal ini dapat dilihat pada output tabel yang sama menunjukkan bahwa nilai t-hitung $=2,003>\mathrm{t}$-tabel $=1,960$. Dengan demikian 
hasil penelitian ini tidak mendukung hipotesis awal yang menyatakan bahwa Motivasi memoderasi hubungan Partisipasi dengan Kinerja Manajerial.

Pelimpahan Wewenang berpengaruh terhadap hubungan antara Partisipasi dengan Kinerja Manajerial SKPD. Hasil pengolahan data diketahui bahwa nilai $=1,630<\mathrm{t}$-tabel $=1,960$, yang artinya menerima Ho. Hal ini berarti bahwa variabel moderasi Pelimpahan Wewenang tidak berpengaruh terhadap hubungan antara Partisipasi dengan Kinerja Manajerial.

Pengetahuan Manajemen Biaya berpengaruh terhadap hubungan antara Partisipasi dengan Kinerja Manajerial SKPD. = 2,125 > t-tabel $=1,960$, yang berarti bahwa Ho ditolak. Artinya bahwa variabel moderasi PMB berpengaruh terhadap hubungan antara Partisipasi dengan Kinerja Manajerial. Hal ini menunjukkan bahwa PMB memoderasi hubungan antara Partisipasi dengan Kinerja Manajerial. Dengan demikian hasil penelitian ini mendukung hipotesis awal yang menyatakan bahwa PMB memoderasi hubungan Partisipasi dengan Kinerja Manajerial SKPD. Hal ini menunjukkan bahwa (PMB) Pengetahuan Manajemen Biaya memoderasi hubungan Partisipasi terhadap Kinerja Manajerial.

\section{PENUTUP}

\section{Kesimpulan}

Berdasarkan hasil analisa data dan pembahasan yang dilakukan pada bab sebelumnya, maka dalam penelitian ini dapat diambil kesimpulan sebagai berikut;

1. Partisipasi dalam penyusunan anggaran, Motivasi dan Pengetahuan Manajemen Biaya mempunyai pengaruh terhadap Kinerja Manajerial di Dinas Instansi SKPD Propinsi Riau.

2. Pengetahuan Manajemen Biaya memoderasi hubungan Partisipasi dengan Kinerja Manajerial Dinas Instansi SKPD Propinsi Riau.

3. Pelimpahan Wewenang tidak mempunyai pengaruh terhadap Kinerja Manajerial Dinas Instansi SKPD Propinsi Riau.

\section{Saran}

Melihat hasil dalam penelitian ini dengan mempertimbangkan adanya keterbatasan, maka saran yang dapat diberikan untuk penelitian lebih lanjut adalah:

Dalam membuat pertanyaan, khususnya yang berkaitan dengan pelimpahan wewenang harus dilakukan dengan baik dan benar serta diperlukan referensi yang cukup untuk membangun suatu instrumen pertanyaan.

Penelitian ini diharapkan bisa memberi kontribusi terhadap instansi SKPD di Provinsi Riau, yang hasil akhirnya ialah meningkatnya kinerja manajerial sehingga memberi dampak positif terhadap masyarakat setempat maupun pada umumnya. 


\section{DAFTAR PUSTAKA}

Brownell .P., 1982a. Participation in budgeting Process: When It Works and it Doen't, Journal of Accounting Literature, 1. hal 124-153.

Ferdinand, Augusty Tae, 2006. Structural Equation Modelling Dalam Penelitian Manajemen, Semarang Badan Penerbit Universitas Diponegoro.

Galbraith.J., 1973. Designing Complex Organizations, Reading, Massachuset: Addison- Wesley Publishing Company.

Ghozali, I., 2006. Aplikasi Analisis Multivariate dengan Program SPSS. Edisi 3. Semarang. Badan Penerbit Universitas Diponegoro.

Juniarti, dan Evelyne, 2003. Hubungan karakteristik informasi yang dihasilkan oleh sistem informasi manajemen terhadap kinerja manajerial pada perusahaan-perusahaan manufaktur di Jawa Timur. Jurnal Akuntansi \& Keuangan, 5 (2). hal. 110-122.

Mahoney, T.A., T.H. Jerdee dan S.J. Caroll, 1963. Development of managerial Performance: A Research Approach, Cincinnati: South Western Publ.Co.

Malayu S.P. Hasibuan, 1996. Organisasi\&Motivasi, Dasar Peningkatan Produktivitas, Jakarta. Bumi Aksara.

Marani dan Supomo, 2003. Motivasi dan Pelimpahan Wewenang Sebagai VariabelModerating Dalam Hubungan Antara Partisipasi Penyusunan Anggaran Dengan Kinerja Manajerial. Journal Riset Akuntasi Indonesia 2 Januari.

Mardiasmo, 2005. Akuntansi Sektor Publik. Yogyakarta. Penerbit Andi.

Merchant,K.A., 1981. The Design of the Corporate Budgeting System: Influences onManagerial Behavior and Performance. The AccountingReview, hal 813-828.

Mia. L., 1998. Managerial Attitude, Motivation and Effectiveness of Budget Participation,Accounting Organazation and Society, 13 (5). hal 465475 .

Milani,K., 1975, The Relationship of Participation in Budget-Setting on Industrial Supervisor Performance and Attitudes: A Field Study. The Accounting Review. April. hal 104-123.

Riyadi, S., 2000. Motivasi dan Pelimpahan Wewenang Sebagai Variabel Moderating Dalam Hubungan Antara Partispasi Penyusunan Anggaran dan Kinerja Manajerial, Jurnal Riset Akuntansi Indonesia, Vol. 3 (2) Juli. hal. 14-150

Riyanto, Bambang, 1997. Strategic Uncertainty, Management Accounting and Performance:An Empirical Investigation of A Contingency Theory at The Firm lavel, Jurnal Riset Akuntansi, Manajemen, Ekonomi 1(1).

Robbins., S.P, 2001. Perilaku Organisasi: Konsep, Kontroversi, Aplikasi. Jilid 1 Edisi Bahasa Indonesia. Jakarta. Prenhallindo.

Sekaran, Uma, 1992. Research Methods for Business: a Skill-building approach, edisi kedua. Canada. John Wiley \& Sons, Inc.

Shields, M., Young, M., 1994. Managing Innovation Costs: A Study of Cost Conscious Behavior by R\&D Professionals. Journal of Management 
Accounting Research 6, hal. 175-196.

Shim, Jae., 2000. Budgeting. Jakarta. Erlangga.

Soetrisno, 2010. Motivasi dan Pelimpahan Wewenang sebagai Partisipasi Penyusunan Anggaran dan Kinerja Manajerial. Seminar Nasional Riset Akuntansi dan Bisnis. Semarang.

Supriyono, 1987. Akuntansi Manajemen I; Konsep Dasar Akuntansi Manajemen dan Proses Perencanaan, Yogyakarta. Edisi 1 BPFE.

Surya Dharma, 2005, Manajemen Kinerja; falsafah Teori dan Penerapannya, Yogyakarta. Pustaka Pelajar. 